\title{
A MAGYAR BIZALMI VAGYONKEZELÉS ÉS VAGYONKEZELŐ ALAPÍTVÁNY MEGÍTÉLÉSE A KEDVEZMÉNYEZETTI JOGOK ÉRVÉNYESÜLÉSÉNEK FÉNYÉBEN
}

https://doi.org/10.51783/ajt.2021.3.02

Tanulmányomban bemutatom, hogy a kedvezményezett jogainak biztositása miként alakitotta ki az angolszász trust klasszikus szabályait, és ezek közül milyen megoldásokat vettek át a hazai jogrendszerbe történő adaptálásakor. Összehasonlítom a magyar bizalmi vagyonkezelés és vagyonkezelő alapítvány megalkotásának szabályát a francia fiducie kialakításának folyamatával, és rámutatok, hogy az EU V. Pénzmosási Irányelvének átültetése milyen új kihívások elé állítja a trust-konstrukciók eddigi jogalkalmazóit. Végül a kedvezményezetti jogok fókuszában megvizsgálom a hatályos magyar szabályozás kialakitásának folyamatát, jelenlegi kihívásait, ezzel rávilágítok a hazai trust-konstrukciók jövőbeni várható fejlődési irányára.

\section{BEVEZETÉS}

Az alapvetően angolszász eredetủ trust jogviszony lényege, hogy egy jogalany megkapja a tulajdonosi döntések meghozatalához szükséges jogosultságokat, miközben a vagyon kezelésével kapcsolatos döntéseit úgy kell meghoznia, hogy az egy másik jogalany (kedvezményezett) vagyonát gyarapítsa. ${ }^{1}$

A jogi konstrukció haszonhúzója a kedvezményezett, ezért az őt megillető jogosultságok és azok biztosítása alapvetően meghatározza a jogviszony természetét.

A „trust-modell” sokáig idegen volt a kontinentális jogrendszerekben, ahol hasonló gazdasági igényekre más jogintézmények (például gazdasági társaság, alapítvány, megbízási jogviszony, meghagyás stb.) kínáltak adekvát megoldásokat.

A modern kor globalizált világában a jogrendszerek egymáshoz való közelítése figyelhető meg. A gazdasági érdekek megkövetelik, a rugalmas megoldásokat kínáló trust-modell kontinentális jogrendszerekbe történő adaptálását. A kilencvenes

* PhD-hallgató, Eötvös Loránd Tudományegyetem Állam- és Jogtudományi Kar, 1053 Budapest, Egyetem tér 1-3. E-mail: borblyzoltan@gmail.com.

1 Vö. VÉKÁs Lajos (szerk.): A Polgári Törvénykönyv Magyarázatokkal (Budapest: Complex 2013) 793. 
évek második felétől kezdve ez az implementációs folyamat megfigyelhető a civiljogi jogrendszerekben. ${ }^{2}$

Magyarországon a Polgári Törvénykönyvröl szóló 2013. évi V. törvény (Ptk.) hatályba lépésével a hazai jog részévé vált a trust és a német Treuhand alapján kialakított bizalmi vagyonkezelés intézménye. A vagyonkezelő alapítványokról szóló 2019. évi XIII. törvény (Vatv.) hatályba lépésével pedig lehetővé vált „a trustjegyeket magán hordozó” vagyonkezelő alapítvány létrehozása is.

Hipotézisem szerint a vagyonkezelési modellek szabályozási fejlődésének meghatározó eleme a kedvezményezetti jogok érvényesítésének biztosítása, ellenőrzési és vagyonvédelmi pozíciójának erősítése. A jogalkotók célja egy olyan rugalmas konstrukció létrehozása, amely a nagytőke számára vonzó, ugyanakkor visszaélésekre sem ad lehetőséget. Ezen két cél közötti egyensúly megtalálása számos különböző trust-konstrukciót hozott létre. Álláspontom szerint alapvetően ez a kívánatos állapot megteremtése adja a jogintézmény fejlődésének dinamikáját.

Tanulmányomban kísérletet teszek annak bemutatására, hogy a kedvezményezett jogainak biztosítása miként alakította ki az angolszász trust klasszikus szabályait, és milyen megoldások születtek a hazai jogrendszerbe történő adaptálásra, végül a kedvezményezetti jogok fókuszában megvizsgálom a hatályos magyar szabályozás kialakításának folyamatát. Egy ilyen áttekintés reményeim szerint felvázolhatja a magyar trust-konstrukciók szabályozásának fejlődési irányát, és rávilágíthat a jogintézménnyel kapcsolatos problémákra, szabályozási kérdésekre.

Munkám elején a jogtörténeti, összehasonlító jogtudományi és dogmatikai eszközökkel megkísérlem bemutatni, hogy a vagyonkezelésből eredő jogok kedvezményezett általi kikényszeríthetősége miképpen befolyásolhatja a jogintézmény fejlődését.

\section{A BIZALMI VAGYONKEZELÉS ANGOLSZÁSZ JOGTÖRTÉNETI ELŐZMÉNYEI}

A trust intézménye az angol common law-ban gyökerezik. ${ }^{3}$ A common law-t leegyszerűsítve a királyi bíróságok joggyakorlatára épült precedensrendszerként definiálhatjuk. ${ }^{4}$

A középkori angol jogban a common law mellett érvényesült az equity, ami a kancellári bírság (Court of Chancery) által kifejlesztett jog. ${ }^{5}$ A kancellári bíróság nem volt alárendelve a common law jogának, így annak alkalmazása folytán esetlegesen

2 Ahogyan Sándor István találóan fogalmaz: „A harmadik évezred elejétől kezdődően egyéb országokban is felismerhető ez a folyamat, amely némi túlzással »végigvonult « Európán (Franciaország, Luxemburg, San Marino, Cseh Köztársaság, Románia, Magyarország), illetve a Közel-Keleten (Dubaj, Katar, Brunei, Bahrein)." - SÁNDor István: A vagyonvédelem jogi eszközeinek legújabb nemzetközi tendenciái (Budapest: HVG-ORAC 2019) 23.

3 SÁNDOR István: A bizalmi vagyonkezelés és a trust. Jogtörténeti és összehasonlító jogi elemzés (Budapest: HVG-ORAC 2017) 35.

4 Ld. IllÉs István: „A trustokról magyar szemmel” in KISFALUdi András (szerk.): Tanulmányok a bizalmi vagyonkezelés jogi szabályozásának elméleti alapjairól (Budapest: Eötvös 2015) 144.

5 SÁndor (3. lj.) 38. 
bekövetkező igazságtalanságokat, ${ }^{6}$ a common law merevségét a kancellári bíróság joggyakorlata enyhítette. A common law és az equity párhuzamossága hasonlóságot mutat a római jogban a ius strictum és a ius honorarium, azon belül is a ius praetorium egymás mellett élésével. ${ }^{7}$

Az equity talaján megszületett a use jogintézménye, amely a trust előzményének számít. A középkori Angliában az ingatlanok tulajdonosa végső soron a király volt, aki a hűséges alattvalók között földet osztott. A megszerzett földek feudális terhet vontak maguk után, és 1540 előtt a common law nem tette lehetővé a végintézkedés szabadságát, így a hübéresek azt nem tudták halál esetére átruházni, hanem az visszaszállt a királyra. A feudális viszonyok hanyatlásával egyre nagyobb igény mutatkozott arra, hogy a bérlő a földet vagy örököseire hagyja, vagy még életében átruházhassa anélkül, hogy a hủbérurától erre vonatkozó engedélyt kérjen. A helyzet megoldására megszületett a use intézménye, amelynek lényege a következőképpen foglalható össze: „A jogviszony meghatározó jellemzője az volt, hogy a vagyonrendelő (feoffor) átruházta vagyonát bizalmi emberére (feoffe), aki meghatározott kedvezményezett (cestui que trust) javára kezelte azt." ${ }^{8}$ Végakaratával vagy más előzetes intézkedésével a feoffor kijelölhette a további használókat is, így lehetővé vált a föld átruházása a hübérúr beleegyezése nélkül. ${ }^{9}$

Ugyanakkor a use intézményét a common law nem ismerte el, így a vagyonkezelő a vagyon felett tényleges teljes tulajdonjogot (legal title) szerzett, és ha a feoffe nem teljesítette a vállalt kötelezettségét, úgy vele szemben a common law bíróság előtt nem léphetett fel sem a vagyonrendelő, sem a kedvezményezett. ${ }^{10}$ Azonban a kancelláriai bíróság az equity alapján keresetet adott a use alapítójának, hogy felléphessen a tulajdonos vagyonkezelő (legal owner) ellen azért, hogy kikényszeríthesse, hogy a tulajdonosi jogait a kezdeményezett javára gyakorolja.

A fentiek miatt a kedvezményezett joga mintegy tulajdonosi jogosítvánnyá (equitable ownership) vált. ${ }^{11} \mathrm{~A}$ common law szerinti tulajdonost tehát kötötte az equity alapján fennálló jogosultság, hogy a tulajdonosi jogosítványait csak a kedvezményezett javára gyakorolhatja. Az angolszász jogirodalom a common law és az equity alapján a tulajdonon fennálló fenti kettősséget a mai napig a tulajdonjog kettéosztásaként fogja fel. ${ }^{12}$

Mint láthatjuk, a bizalmi vagyonkezelő felelőssége és a jogintézmény megteremtő megállapodás kedvezményezett általi kikényszeríthetősége adja a jogi konstrukció lényeges elemét. A kikényszeríthetőség biztosítása az angol jogban a trust máig

6 Vö. IllÉs (4. lj.) 144.

7 Hamza Gábor is számos hasonlóságot is felfedezni vél a praetori edictumok és az angol equity között. In: Hamza Gábor: Az európai magánjog fejlődése (Budapest: Nemzeti Tankönyvkiadó 2002) 82. A kapcsolódási pontokra Sándor István is rámutat: SÁNDor (3. lj.) 35. és 38.

8 SÁndor István: „Kísérletek az angolszász trust civiljogi átvételére” in SÁndor István [et al.] Acta Facultatis Politico-Iuidica Univesitatis Budapestinensis De Rolando Eötvös Nominatae. Tom. LI. (Budapest: Eötvös 2014) 39.

9 Vö. SÁndor (3. lj.) 55.

${ }^{10}$ Ld. Szladits Károly: Az angol jogi trust-intézmény (Budapest: Tébe Kiadóvállalata 1939) 11.

11 Vö. SÁndor (3. lj.) 63.

12 Vö. Maurizio LuPoI: „The civil law trust” Vanderbilt Journal of Transnational Law 1994/4. 12. 
meghatározó eleme, így főszabály szerint a vagyonkezelői jogosultság ellensúlyozásának biztosítása érdekében megkövetelik kedvezményezettek meglétét (ún. beneficiary principle). ${ }^{13}$

Később, amikor a trust jogi személy formájában történő alapítását is lehetővé tették, megjelentek az ún. „unit trust”-ok is, amelyek az alapítási engedélyhez kötött részvénytársaságok helyett sokkal rugalmasabb konstrukciót kínáltak a befektetőknek. A XX. századtól kezdődően a trust rugalmas konstrukciója miatt gazdasági igény mutatkozott a jogintézmény kontinentális jogrendszerbe történő adaptációja iránt. Azonban a tulajdonjog kettőssége és a kedvezményezett dologi jogi jellegű igénye idegen természetủ volt a civiljogi jogrendszerekben, amely az átvétel nehézségét jelentette.

\section{A KEDVEZMÉNYEZETT JOGÁNAK KÖTELMI VAGY DOLOGI JOGI TERMÉSZETE}

A trust-konstrukció kontinentális jogrendszerekben történő átvétele során szintén élénk vita alakult ki arról, hogy a kedvezményezett igénye kötelmi jogi (ius in personam) vagy dologi jogi (ius in rem) jellegűnek minősíthető-e. A kérdésre adott válaszok függvényében dönthető el, hogy milyen formában kerüljön sor a szabályozás kialakítására.

$\mathrm{Az}$ angol szakirodalomban az egyik, ún. realista iskola álláspontja szerint a kedvezményezett jogát dologi jognak tekinti, mert a trustee csődje vagy trust-vagyon harmadik személynek történő elidegenítése szerint a kedvezményezett dologi jogi igénnyel felléphet a hitelezőkkel, vagy harmadik személlyel szemben. ${ }^{14}$ Ezt a jogot, amelyet a kedvezményezett a kezelt vagyon helyreállítása érdekében támaszthat, és kvázi nyomon követheti a trust-vagyon útját „tracing rules”-nak vagy „tracing”nek nevezik. ${ }^{15}$

Maitland azonban rámutatott arra az ellentmondásra, hogy a kedvezményezett ius in rem-je a jóhiszemű ellenérték fejében szerző harmadik személlyel szemben nem érvényesíthető (bona fide purchaser for value), így ez mégsem tekinthető abszolút jognak. ${ }^{16}$ Ugyanakkor A. W. Scott álláspontja szerint az, hogy a jóhiszemű ellenérték fejében szerző személlyel szemben nem támaszthat dologi jogi igényt, de mindenkivel szemben igen, még nem jelenti azt, hogy kedvezményezett jogosultsága ne volna ius in rem. ${ }^{17}$

A Maitland által képviselt másik álláspont a trust-ot kötelmi jogi jogintézménynek fogja fel. Abban a szakirodalom is egyetért, hogy a vagyonkezelő és a kedvezménye-

13 Bizonyos esetekben megengedi meghatározott célok elérése céljából ún. purpose trustok alapítását, például charitable trustok esetén. Ld. Charlie Weвв - Tim Akкоuн: Trust Law. (London: Palgrave Macmillan ${ }^{3}$ 2013) 131. és Charles E. Jr Rounds - Charles E. Rounds - Augustus Peabody LoRING: Loring and Rounds, a Trustee's Handbook (Austin: Wolters Kluwer Law \& Business $\left.{ }^{8} 2010\right)$ 5-7.

14 Vö. Szladits (10. lj.) 165.

15 Weвв-AккоUн (13. lj.) 361-362.

16 Ld. SÁNDOR (2. lj.) 151.

17 Vö. Szladits (10. lj.) 165. 
zett között kötelmi viszony áll fenn, mert a vagyonkezelői kötelezettség megsértése esetén (breach of trust) a kedvezményezett kártérítési igénnyel léphet fel. Maitland ezenfelül a kötelemi jogi érv megalapozásához jogtörténeti érvet is felhoz. Szerinte a kancellár bírósága sub poena védelme hozta létre a trust-ot, amely in personam hatott, de a kancellár bíróságának nem állt módjában létrehozni új dologi jogi in rem jogot, és a trust kialakulásának előnye a tulajdonost terhelő korlátozások és terhek kijátszása volt, ha már most a kedvezményezett tulajdonjogot szerzett volna, akkor megszűnt volna minden előny, amely ezt a jogintézményt létrehozta. ${ }^{18}$

Napjainkban a Trust kommentár szintén kötelmi jogi igénynek minősíti a trust jogi jogviszonyt. ${ }^{19} \mathrm{~A}$ fenti visszaköveteléssel kapcsolatos dologi jogosultságot pedig - köztük Lionel Smith - azzal magyarázzák, hogy az angolszász jog másként értelmezi a kötelmet, kevésbé koncepcionális, mint a civiljog és így a kedvezményezett harmadik személyekkel szemben is fel tud lépni, ha az nem volt jóhiszemű vagy nem ingyenesen szerzett. ${ }^{20}$

A teljesség igénye érdekében megemlíthető, hogy van egy Hanbury által is képviselt harmadik nézet is, amely a kötelmi és dologi jog határán helyezi el a kedvezményezett jogi helyzetét. ${ }^{21}$

A fenti szakirodalmi álláspontok alapján megállapítható, hogy a kedvezményezett jogi helyzetét inkább kötelmi jellegűnek lehet minősíteni. Ugyanakkor a tracing szabálya révén a kedvezményezett vindikációs jogot kap az olyan harmadik személyekkel szemben, akik a kezelt vagyonból rosszhiszeműen vagy ingyenesen szereznek. A nyomon követés valódi vindikációs jogot jelent, mivel nem kártérítésre, hanem a kezelt vagyon természetbeni helyreállítására irányul. ${ }^{22}$

$\mathrm{Az}$ angolszász szakirodalomban nem alakult ki egységes álláspont a kedvezményezett jogait illetően. A kettős tulajdoni helyzet és a kedvezményezettet megillető vindikációs jog komoly kihívások elé állította a kontinentális jogalkotókat, ezért a nemzetközi gyakorlat is meglehetősen vegyes képet mutat a kedvezményezett trust kikényszerítésére vonatkozó jogának biztosítását illetően. A legszélsőségesebb megoldást a Kajmán-szigeteki jogalkotás mutatja, ami általános jelleggel mondja ki, hogy a kedvezményezettnek nincs joga a trust kikényszerítésére, a vagyonkezelővel szembeni fellépésre vagy a kezelt vagyonra. ${ }^{23}$ Ehhez képest, ahogyan később látni fogjuk, a magyar szabályozás szélesebb jogköröket biztosít a kedvezményezett igényérvényesítésére, valamint a hazai szabályozás tekintetében a jogalkalmazók részére a bizalmi vagyonkezelés mellett a vagyonkezelői alapítvány létrehozása is lehetővé vált, amely amellyel a jogalkotó a létrehozható vagyonkezelési konstrukciók körét kiszélesítette.

${ }^{18}$ Frederic William Maitland: Equity. Also the Forms of Action at Common Law (Cambridge: Cambridge University Press 1910) 31.

${ }^{19}$ SÁndoR (3. lj.) 170.

${ }^{20}$ Sándor István idézi Lionel Smith-t: SáNDoR (3. lj.) 170.

${ }^{21}$ „Equitable rights and intrests must, then be regarded as hybrids, standing midway between jura in personam and jura in rem." H. G. HanBurY: The Field of Modern Equity (London: Law Quarterly Review 1929) 55. és 62.

22 SÁNDOR (3. lj.) 149.

${ }^{23}$ SÁNDOR (3. lj.) 184. 
A következőkben ezen jogintézmények hazai szabályozásának kialakítását elemzem, összehasonlítva a hasonló fejlődésen átesett francia „fiducie” intézményének kialakításával érintve a trust-konstrukciók szempontjából kihívást jelentő tényleges tulajdonosok nyilvántartására vonatkozó szabályozást is. Végül a hatályos magyar joganyag alapján a kedvezményezett jogai érvényesíthetőségének lehetőségeit veszem górcső alá.

\section{A TRUST-JELlEGÜ KONSTRUKCIÓK HAZAI KIALAKÍTÁSA}

\subsection{A MAGYAR TRUST-KONSTRUKCIÓK KIALAKÍTÁSA}

Az új Ptk. megalkotásával a hazai jog részévé vált a bizalmi vagyonkezelés intézménye. A kialakított szabályozás a vagyonkezelő személye szerint differenciált. Az eseti vagyonkezelőre irányadó enyhébb általános szabályokat a Ptk. tartalmazza. Az üzletszerűen eljáró bizalmi vagyonkezelőre vonatkozó szigorú szabályozást a bizalmi vagyonkezelökről és tevékenységük szabályairól szóló 2014. évi XV. törvényben (a továbbiakban: Bvktv.) helyezték el. Ez alapján bizalmi vagyonkezelő vállalkozás csak a Magyar Nemzeti Bank (MNB) engedélyével működhet, és legalább hetvenmillió forint összegủ saját tőkével és ezen felül legalább hetvenmillió forint összegủ pénzügyi biztosítékkal köteles rendelkezni.

A Bvktv.-t a jogalkotó a pénzügyi piacok müködését és a pénzügyi eszközök kereskedését szabályozó törvények jogharmonizációs célú módosításáról szóló 2017. évi LXI. törvénnyel több helyen módosította, pontosította, a korábbi szabályozást egyértelműsítette és az adminisztrációs előírások vonatkozásában jelentősebb deregulációt hajtott végre. A 2017. évi LXI. törvénnyel az ügyvédi irodák számára is lehetőség nyílt arra, hogy üzletszerűen bizalmi vagyonkezelést végezzenek. Ugyanakkor az eredeti engedélyezési feltételek, a hetvenmillió forint összegű szavatoló tőke és a pénzügyi biztosítékra vonatkozó feltételek továbbra is fennmaradtak. A módosítás egyértelmủ célja az volt, hogy a hazai szabályozás átalakításával az üzleti környezet jogi versenyképességét növelje úgy, hogy ez a konstrukció még vonzóbbá váljon a magyar és a külföldi befektetők számára. A jogalkotó ugyanezen célból $^{24}$ 2019. év elején a vagyonkezelő alapítványokról szóló 2019. évi XIII. törvény (Vatv.) megalkotásával a magyar jog részévé tette a vagyonkezelő alapítvány intézményét. A vagyonkezelő alapítvány megalkotásával a Vatv. a világon elsőként vezette be az ún. hibrid trust megoldását, amely lehetőséget teremt arra, hogy a vagyonkezelő alapítvány nemcsak a javára rendelt, hanem az áltata bizalmi vagyonkezelésbe vett vagyon kezelését is végezheti. ${ }^{25}$

Az Országgyủlés kormánypárti többsége a német nemzetiségi szószóló és kettő független országgyülési képviselő szavazatával 2021. április 28. napjától külön törvényben, a közfeladatot ellátó közérdekü vagyonkezelő alapítványokról szóló

${ }^{24}$ Ld. a 2019. évi XIII. törvény általános indokolását.

${ }^{25}$ B. Szabó Gábor - Menyhei Ákos - SÁndor István: Az alapítvány. Történeti, tipológiai, müködési, adózási és vagyonkezelési omnibus (Budapest: HVG-ORAC 2021) 107. 
2021. évi IX. törvény (Kekva tv.) helyezte el a közfeladatot ellátó közérdekű vagyonkezelő alapítványokat érintő szabályozást. A külön törvény megalkotásának célja a hatékonyság és a hosszú távú stabil müködés biztosítása, a Kekva tv. indokolása szerint a közfeladatot ellátó közérdekű vagyonkezelő alapítványok a mindenkori kormányzattól független, magánjogi formában biztosítják a társadalom számára kiemelten fontos közérdekủ céljaik megvalósítását. ${ }^{26}$

Az ellenzéki pártok közül a Jobbik, az MSZP, a DK, az LMP és a Párbeszéd a Kekva tv. valamint az azzal összefüggő, alapítványi tisztviselők összeférhetetlenségére vonatkozó egyes jogállási törvényi rendelkezések alaptörvény-ellenességének megállapítását és kihirdetésükre visszamenőleges megsemmisítését kérték az Alkotmánybíróságtól. Álláspontjuk szerint a külön törvény megalkotása „egyszerű pénz- és hatalommentés, semmi több" 27 , így a taláros testülethez intézett beadványukban is elsőként a Kekva tv. azon rendelkezéseit kifogásolták, amelyek álláspontjuk szerint a közfeladatot ellátó közérdekű vagyonkezelő alapítványok közjogi jellegének teljes felszámolására irányulnak. ${ }^{28}$ A Transparency International Magyarország Alapítvány amicus curiae beadványában a Kekva tv. 11.§ (3) bekezdésének ${ }^{29}$ vissza- $^{-}$ menő hatállyal történő megsemmisítését kérte, mert álláspontjuk szerint a rendelkezés összeegyeztethetetlen a nemzeti vagyonnal való gazdálkodás alkotmányos követelményével. ${ }^{30}$ Jelen tanulmány írásakor az Alkotmánybíróság döntése még nem ismert.

A vagyonkezelő alapítvány magyar szabályozásának kialakítása szorosan összefügg a felsőoktatás átalakításának társadalmi és politikai vitáktól nem mentes kérdésével is. Figyelemmel arra, hogy a kapcsolódó társadalmi és politikai kontextus feltárása meghaladná a jelen tanulmányom kereteit, ezért a továbbiakban a vagyonkezelői alapítvány hazai szabályozásának kialakítását elsősorban a kedvezményezetti jogok tükrében annak jogi oldaláról elemzem.

\subsection{A MAGYAR VAGYONKEZELÖI ALAPÍTVÁNY SZABÁLYOZÁSA}

A magáncélú alapítvány hasonló funkciót tölt be, mint az angolszász jogrendszerekben a jótékonysági (ún. „charitable”) trust. ${ }^{31}$ A kettő között azonban lényeges különb-

${ }^{26}$ Ld. 2021. évi IX. törvény általános indokolás.

27 Doмокоs Erika: „Százmilliárdok új alapítványoknak - vétózhat az Alkotmánybíróság?” Napi.hu, 2021. április 29., https://www.napi.hw/magyar-gazdasag/ellenzek-vagyonkezelo-alapitvanykozpenz-egyetem-alkotmanybirosag.728126.html.

${ }^{28}$ Lásd: http://public.mkab.hw/dev/dontesek.nsf/0/6A96C3F521143E12C12587640033DD6C?OpenDocument.

${ }^{29}$ Kekva tv. 11. § „(3) Az alapítvány az állam által juttatott vagyont és annak hozamát közvetlenül vagy közvetett módon a közfeladatra, illetve közérdekű célra fordítja. Ennek során az alapítvány a piaci magánbefektető elvével összhangban gazdálkodási tevékenységet végezhet, ami nem veszélyeztetheti a közfeladat-ellátást. E gazdasági tevékenységek költségeit és bevételeit számvitelileg elkülönítetten tartja nyilván."

${ }^{30}$ Lásd: http://real.mtak.hw/36993/1/amicus_curiae.pdf.

31 Coing szerint a charitable trust funkcióját az alapítvány biztosítja a német jogban: Helmut CoING: „Übernahme des Trusts in unserer internationales Privatrecht?” in Friedrich KüBLER Hans-Joachim Mertens - Winfried Werner (eds.): „Festshrift für Theodore Heinsius zum 65. 
ségek vannak. ${ }^{32} \mathrm{Az}$ egyik, hogy az alapítvány jogi személy, míg a kezelt vagyon nem az. A másik, hogy az alapítvány célra rendelt vagyontömeg, míg a bizalmi vagyonkezelés elsődlegesen személyek érdekében alkalmazott konstrukció. ${ }^{33} \mathrm{Ez}$ utóbbi különbség azonban elhalványulni látszik azon jogrendszerek esetében, amelyek megengedik, hogy a személyek magáncélra is létesítsenek alapítványokat.

A vagyonkezelő alapítvány funkciója a trusthoz hasonló, nevezetesen az, hogy az alapítvány az alapító okiratban megjelölt kedvezményezett, illetve kedvezményezettek számára vagyoni juttatást teljesítsen. A kedvezményezetti körhöz kapcsolódóan a bizalmi vagyonkezeléstől eltérően a Vatv. lehetőséget ad arra is, hogy a vagyonkezelő alapítványt közérdekű célra is létrehozzák, amelyhez speciális szabályokat is társit.

A Ptk. kedvezményezett és közeli hozzátartozója kuratóriumi tagságát tiltó és az alapító, csatlakozó, valamint ezek hozzátartozójának kedvezményezettként történő kijelölését korlátozó szabályát a Vatv. ${ }^{34}$ csak a közérdekű vagyonkezelői alapítványra tartja fenn, ezzel jelentős rugalmasságot teremt a magáncélú alapítványok létesítése terén.

Továbbá a közérdekủ vagyonkezelői alapítvány egyik konjunktív feltétele, hogy kedvezményezettjeinek köre nyílt legyen, vagyis juttatásait ne elöre meghatározott zárt személyi körben nyújtsa. A contrario értelmezés esetén felmerülhet a kérdés, hogy nyitott kedvezményezetti körrel magáncélú vagyonkezelői alapítvány alapítható-e.

A Vatv. nem írja elő, hogy csak meghatározott kedvezményezetti kör vonatkozásában alapítható magánalapítvány. A mögöttes Ptk. pedig az alapító okirat körében csak szükség szerint írja elő a kedvezményezett körének meghatározását. ${ }^{35}$ Fézer Tamás véleménye szerint amennyiben konkrétan nem nevesítik a kedvezményezettet az alapító okiratban, a kedvezményezettek körének meghatározásáról való rendelkezés nem nélkülözhető. ${ }^{36}$

Fézer is elismeri ugyan, hogy a Ptk. úgy rendelkezik, hogy amennyiben az alapító okirat nem jelöli ki a kedvezményezettet, úgy a kezelő szerv dönthet arról, ${ }^{37}$ de álláspontja szerint ez a döntés is kizárólag az alapító okirat által determinált szempontok szerint történhet. ${ }^{38} \mathrm{Az}$ eddig bejegyzett vagyonkezelői alapítványok többsé-

Geburtstag am 25. September 1991" (Berlin-New York: Walter de Gruyter 1991) 82., https://doi. org/10.1515/9783110894837.79.

32 B. Szabó Gábor és szerzőtársai hiánypótló, átfogó munkájukban több szempontrendszer, így a döntéshozatali szervezet, ellenőrzés és kockázatértékelés, valamint a hitelezői jogviszonyok helyzete szerinti is összehasonlítják a vagyonkezelő alapítvány és a bizalmi vagyonkezelés intézményét. B. Szabó-MenYhei-SÁndor (25. lj.) 106-111. és 129-134.

${ }^{33}$ Vö. SÁNdor (3. lj.) 269.

${ }^{34}$ Vatv. 4. $§(4)$ bekezdés.

35 Ptk. 3:391. $§(2)$ bekezdés i) pont.

${ }^{36}$ FÉzer Tamás: „A Ptk. 3:391. §-hoz füzött magyarázata” in OszTovits András (szerk.): A Polgári Törvénykönyvröl szóló 2013. évi V. törvény és a kapcsolódó jogszabályok nagykommentárja (Budapest: Opten ${ }^{1}$ 2014) 1040.

37 Ptk. 3:385. §.

38 FÉZER (28. lj.) 1040. 
géről rendelkezésre álló közhiteles nyilvántartás adatainak ${ }^{39}$ vizsgálatából látható, hogy a kedvezményezettek megjelölése csak az alapító személyi egyezősége esetén konkrét, név szerint megjelölt. Azonban ezen esetekben is a kedvezményezetti kör kiterjed a nevesített személy családjára, gyermekeire, valamint még meg nem született leszármazóira.

A fentiekből következően az eddigi magyar bírói gyakorlat azt mutatja, hogy a vagyonkezelői alapítvány alapításához elegendő lehet a konkrét kedvezményezett megjelölése helyett az alapítói okirat olyan rendelkezése is, amely meghatározza a kedvezményezetti kör egyértelmű beazonosításához szükséges szempontrendszert. A kedvezményezetti kör meghatározásával és a juttatás mértékének és kiadásának időpontjával kapcsolatos alapítói jogok pedig a kuratóriumra átruházhatóak, így létrehozható egy angolszász jogrendszerben a „discretionary trust”-hoz hasonló konstrukció, ahol a vagyonkezelő dönthet a kezelt vagyon a kedvezményezett személyek részére történő kiadásáról.

A hazai vagyonkezelői alapítványi szabályozás vizsgálata körében megállapítható, hogy ez „egy hibrid megoldást jelent az üzletszerủ és az eseti vagyonkezelési modell között." ${ }^{40} \mathrm{Az}$ eseti bizalmi vagyonkezeléssel mutat hasonlóságot, hogy az alapítvány csak egy vagyonrendelési jogviszonyban lehet vagyonkezelő, míg az üzletszerű bizalmi vagyonkezelésben abban hasonlít, hogy ott a vagyonkezelő jogi személy. ${ }^{41}$ A megállapítást annyiban lehetne még kiegészíteni, hogy a jogviszony a Bvktv.-ben szereplő pénzügyi biztosíték és egyéb engedélyezési feltételek hiánya miatt inkább az ad hoc bizalmi vagyonkezelővel mutat hasonlóságot. Szervezeti és a hatszázmillió forint összegű tőkeminimum ${ }^{42}$ előírása szempontjából azonban üzletszerű bizalmi vagyonkezelő szabálya felé közelít, így valóban hibrid megoldásnak lehet tekinteni.

\subsection{A MAGYAR SZABÁLYOZÁS KIALAKÍTÁSÁNAK VIZSGÁLATA EURÓPAI KITEKINTÉSSEL}

\subsubsection{A MAGYAR ÉS A FRANCIA SZABÁLYOZÁS KIALAKÍTÁSÁNAK ÖSSZEHASONLÍTÁSA}

A kívánatos konstrukciók megalkotása során a kedvezményezetti igények és a viszszaélések elkerülése mentén igyekeztek a jogalkotók a szabályozásaikat kialakítani. A trust-modell magyar szabályozásának folyamata több szempontból hasonlóságot mutat a francia fiducie kialakításával.

39 2020.11. 7. napján lekérdezve a Civil szervezetek közhiteles névjegyzékéből. Azon alapítványok, amelyek a vagyonkezelő megnevezést a nevükben hordozzák és a Vatv. rendelkezései alapján jöttek létre, a következők: Primus Vagyonkezelő Alapítvány; Keresztes Vagyonkezelő Alapítvány; HF Vagyonkezelő Alapítvány; Elite Nyugdíjaskastélyok Vagyonkezelő Alapítvány.

${ }^{40}$ SÁndor (3. lj.) 279.

41 SÁndor (3. lj.) 279.

${ }^{42}$ Vatv. 3. § (1) bekezdés. 
Franciaországban a trust átvételét gátolta azon kritikusok álláspontja, akik elsősorban a pénzmosás és adóelkerülés lehetőségét vélték felfedezni benne, valamint dogmatikai kifogásként az osztott tulajdon nem kívánatos lehetősége miatt ellenezték a bevezetését. ${ }^{43}$ A fiducie 2007-es bevezetését követően további módosítások váltak szükségessé. ${ }^{44} 2009$-es módosítás során például lehetővé vált, hogy ügyvédek is lehetnek bizalmi vagyonkezelők. ${ }^{45} \mathrm{Ez}$ hasonlóságot mutat a magyar Bvktv. 2017-es módosításával.

Franciaországban a jogintézménnyel szembeni félelmek a bevezetést követően is fennmaradtak, ezért a pénzmosás elleni harc és adóelkerülés érdekében nyilvántartásba vételi kötelezettséget írtak elő a vagyonkezelői jogviszonyokról. 2010 márciusában létrehozták az országos nyilvántartást. ${ }^{46}$

A nyilvántartásba vételi kötelezettség a hazai szabályozással is hasonlóságot mutat. Magyarországon a bizalmi vagyonkezelői vállalkozás létrehozása jegybanki engedélyhez kötött, amelyről az MNB nyilvántartást vezet. A vagyonkezelői alapítványra nem terjed ki a Bvktv. hatálya. ${ }^{47}$ Ebből kifolyólag a vagyonkezelő alapítvány alapításhoz nem szükséges engedély, azonban létrehozása jogi személyként bíróság általi nyilvántartásba vételhez kötött, ezáltal konstitutív hatályú. Azonban ezzel a jogintézmény a bizalmi vagyonkezeléshez képest előnyéből keveset veszít, mert az eseti vagyonkezelési jogviszonyra vonatkozóan is deklaratív hatállyal ugyan, de nyilvántartásba vételi kötelezettséget a Bvktv. előír., azaz a nyilvántartásba vétel folyamata még az ad hoc bizalmi vagyonkezelési jogviszony esetében sem elhagyható.

A francia parlament 2013. december 6-án törvényt ${ }^{48}$ fogadott el az adócsalás elleni küzdelemröl, az adóelkerülést a trust átláthatóságának növelésével és a nyilvánosság nagyobb bevonásával kívánta csökkenteni. ${ }^{49}$ A jogszabály kapcsán azonban a francia Alkotmánybíróság a magánélethez való jog, valamint a személyes adatok védelme érdekében eltörölte a teljes nyilvánosság biztosítására vonatkozó rendelkezést, így azt, hogy bárki számára betekintést biztosítsanak a kedvezményezett személyét illetően, valamint döntésében az adóelkerülés céljából arányos szabályozás kialakítását szorgalmazta. ${ }^{50}$

${ }^{43}$ Vö. VÉKÁs Lajos: „Bizalmi vagyonkezelés Franciaországban és Svájcban” in KISFALUdi András (szerk.): Tanulmányok a bizalmi vagyonkezelés jogi szabályozásának elméleti alapjairól (Budapest: Eötvös 2015) 74.

${ }^{44}$ De Roux, Xavier: Rapport No. 3655 pour l'Assemblée Nationale. 1.2.2007. 2021.07.18., https:// www.assemblee-nationale.fr/12/rapports/r3655.asp\#P184_21457.

45 Code Civil 2015. cikk.

${ }^{46}$ VÉKÁs (37. lj.) 79.

47 Vatv. 2. $\S(3)$ bek. c) pont.

${ }^{48}$ LOI n 2013-1117 du 6 décembre 2013 relative à la lutte contre la fraude fiscale et la grande délinquance économique et financière

49 Arnaud TAILFER - Stephanie AufÉRIL: „Register of trusts and privacy: French case law in perspective with the fifth Anti-Money Laundering Directive register” Trust \& Trustees 2018/28. 970., https:// doi.org/10.1093/tandt/tty157.

${ }^{50}$ Conseil Constitutionnel Décision n²016-591 QPC du 21 octobre 2016. 


\subsubsection{AZ EURÓPAI UNIÓ V. PÉNZMOSÁS ELLENI IRÁNYELVÉNEK HATÁSA A TRUST-KONSTRUKCIÓK SZABÁLYOZÁSÁRA}

A francia törvényhozás az európai jogalkotás indikátorának tekinthető abból a szempontból, hogy Az Európai Parlament és a Tanács (EU) 2018/843 Irányelve a pénzügyi rendszerek pénzmosás vagy terrorizmusfinanszírozás céljára való felhasználásának megelőzéséről szóló (EU) 2015/849 irányelv, valamint a 2009/138/ EK és a 2013/36/EU irányelv módosításáról (a továbbiakban: Irányelv) már kifejezetten elöírja a tagállamoknak közös nyilvántartás létrehozását a tényleges tulajdonosokról, amelybe a vagyonrendelő, vagyonkezelő és a kedvezményezett is beletartozik. ${ }^{51}$ A nyilvántartás adatait öt, legfeljebb tíz évig meg kell őrizniük, és abból adatokat az igényelhet, aki jogos érdekét igazolja. ${ }^{52} \mathrm{Az}$ Irányelv alapján a tagállamoknak a nyilvántartást 2020. március 10. napjáig létre kell hozniuk. ${ }^{53}$

Az Egyesült Királyságban a témával foglalkozó cikkek nyilvántartásba történő regisztráció kiterjesztésével kapcsolatban több is kritikát megfogalmaztak. Például, hogy az eljárásokat költségesebbé, bürokratikussá teszi, valamint a magánélethez való jogot és a személyes adatok védelmét is sértheti, ennek eredményeként a trustalapítási kedvet visszavetheti. ${ }^{54}$

Magyarország az Irányelv átültetése kapcsán létrehozta ${ }^{55}$ a tényleges tulajdonosok nyilvántartását. A 2022. július 1-jén hatályba lépő rendelkezések értelmében, harmadik személy díj fizetése ellenében egyedi adatszolgáltatás keretében, a nyilvántartó szerv által meghatározott módon adatot igényelhet a bizalmi vagyonkezelési jogviszony tényleges tulajdonosi adataira vonatkozóan, ha az adat felhasználásának célját és az adat megismeréséhez füződő vagy a pénzmosás és terrorizmus finanszírozása elleni küzdelemhez kapcsolódó jogos érdekét okirattal igazolja. ${ }^{56} \mathrm{~A}$ jogalkotó felismerte azt, hogy a tényleges tulajdonosok nyilvántartásába történő betekintési jog kiszélesítése a kedvezményezettek anonimitását és személyes adataik védelmét érzékenyen érintheti, így a jogszabály a pénz-, tőke- és biztosítási piac szabályozásáért felelős miniszterhez benyújtandó előzetes engedély megadásához köti a harmadik személy általi megismerési jog teljesítését.

A tényleges tulajdonosok nyilvántartása a közalapítványok és a pártalapítványok kivételével az alapítványokra is kiterjed. ${ }^{57}$

Megemlíthető, hogy a pénzmosás és a terrorizmus finanszírozása megelözéséről és megakadályozásáról szóló 2017. évi LIII. törvény (Pmt.) 3. § 38. d) pontja 2020. január 10. napjától már az alapítványok tényleges tulajdonosának fogalmával is kiegészült. A szabályozás elsősorban az alapítványi vagyon legalább huszon-

${ }^{51}$ Irányelv 16. cikk.

${ }^{52}$ Irányelv (28) és (46) bekezdése és 15 . cikk.

${ }^{53}$ Irányelv (53) bekezdés.

${ }^{54}$ Emma Agyemang: „Could new regulation spell the death of trusts?” Financial Times, 2020. január 17., https://www.ft.com/content/fc22bb5f-133e-4bf9-8e1c-6dc7ad5aeb3e.

${ }^{55}$ A pénzügyi és egyéb szolgáltatók azonosítási feladatához kapcsolódó adatszolgáltatási háttér megteremtéséről és müködtetéséről szóló 2021. évi XLIII. törvény.

56 2021. évi XLIII. törvény 8. § (7) bekezdés.

${ }^{57}$ 2021. évi XLIII. törvény 1. § (1) bek. 27. pont. 
öt százalékát elérő kedvezményezettet tekinti tényleges tulajdonosnak, míg bizalmi vagyonkezelők esetében valamennyi kedvezményezettet is. ${ }^{58} \mathrm{~A}$ Vatv. 2 . § a) pontja a vagyonkezelő alapítvány által bizalmi vagyonkezelésbe adott vagyon tekintetében a kedvezményezetti kört is kógensen meghatározza úgy, hogy csak az alapítvány jelölhető ki kedvezményezettnek. A fentiekből következően huszonöt százalék alatti kedvezményezettek esetén az alapítvány vezetői tekinthetők tényleges tulajdonosnak, így az anonimitás ebben a tekintetben alapítványi konstrukció esetén jobban biztosítható.

\section{A KEDVEZMÉNYEZETTET MEGILLETŐ JOGOK HAZAI SZABÁLYOZÁSÁNAK VIZSGÁLATA}

Az egyes vagyonkezelői konstrukciók elterjedésének prognosztizálásához mindenekelőtt szükséges megvizsgálni a kedvezményezettet megillető jogok hazai szabályozását a bizalmi vagyonkezelés és a vagyonkezelői alapítvány esetén.

\subsection{A KEDVEZMÉNYEZETT IGÉNYÉRVÉNYESÍTÉSÉNEK LEHETŐSÉGE A VAGYON KIADÁSA IRÁNT}

Az igényérvényesítés szempontjából kedvezményezett jogai a vagyonrendelöhöz vagy alapítóhoz képest kevésbé biztosítottak, hiszen ő a jogviszony létrehozásában nem szükségszerủen szerződő fél, így például a bíróság általi szerződésmódosítást sem kezdeményezheti. A vagyonkezelő jogsértésével szemben bizalmi vagyonkezelés esetében a szerződés a Ptk. vagy a Bvktv. megszegésére alapíthat igényt. A vagyonkiadása iránt a kedvezményezett hitelezői pedig csak akkor léphetnek fel, ha a kezelt vagyon kiadása a kedvezményezett számára már esedékessé vált. ${ }^{59}$

A Ptk. nem nevesíti, azonban a diszpozitivitás alapján lehetősége van arra a vagyonrendelőnek, hogy a vagyonkezelő ellenőrzésére egy harmadik külső személyt, ún. protektort nevezzen ki. A protektor kinevezéséből adódóan a vagyonrendelő megbízásából jár el, így annak halála esetén a protektor jogállása is megszűnhet kivéve, ha a Ptk. 6:325. § (4) bekezdése alapján a vagyonrendelő szerződésben halála vagy jogutód nélküli megszűnése esetén, az őt megillető jogok gyakorlására és az őt kötelezettségek teljesítésére harmadik személyként a protektort jelölte ki. Ugyanakkor figyelemmel arra, hogy a Ptk. a protektor személyét a fenti esetkörön kívül nem ismeri, így a protektor általi perindítás lehetősége is csak a szerződés alapján dönthető el.

A Vatv. ugyanakkor alapítványi vagyonellenőrként kifejezetten nevesíti a protektor személyét, és kinevezését kötelezőnek írja elő a magán vagyonkezelő alapítvány esetén, ha az alapító az alapítói jogok gyakorlására a kuratóriumot jelölte ki, illetve e

${ }^{58}$ Vö. Pmt. 3. § 38. ec) pont.

${ }^{59}$ Ptk. 6:314. § (2) bekezdés. 
jogait az alapítványra ruházta át. ${ }^{60} \mathrm{~A}$ Kekva tv. pedig az alapítványi vagyonellenőr kijelölését kötelezően írja elő. ${ }^{61} \mathrm{~A}$ Vatv. és a Kekva tv. is az alapítványi vagyonellenőrre vonatkozóan ellenőrzési és törvényességi felügyeleti eljárás kezdeményezésére, valamint, ha az alapító okirat erre feljogosítja határozat hatályon kívül helyezése iránt perindítási jogosultságot biztosít. ${ }^{62} \mathrm{Az}$ alapítványi vagyonellenőr a vagyonkezelési tevékenységének jogszerűségének figyelemmel kísérésével segíti elő az alapítványi cél megvalósítását, és így óvja a kedvezményezetti érdekeket is. Azonban ez nem jelenti azt, hogy a kedvezményezett utasítási joggal vagy bármilyen ráhatással lehetne a vagyonellenőr tevékenységére.

A Ptk. ${ }^{63}$ a bizalmi vagyonkezelés körében nevesíti a kedvezményezetteket megillető ellenőrzési jogosultságot, valamint a kedvezményezett számára vindikációs jogot biztosít, ha a szerződés alapján a kezelt vagyon kiadása esedékessé vált. A Ptk. alapítványok esetén főszabály szerint nem teszi lehetővé, hogy a kedvezményezett igényt támasszon az alapítvánnyal szemben. ${ }^{64} \mathrm{~A}$ Vatv. a Ptk. fenti szabályától történő eltérést pedig csak magáncélú alapítványok esetén teszi lehetővé. ${ }^{65}$ Továbbá a Vatv. előírja, hogy az alapító okirat módosítása vagy az alapítvány megszünése nem érinti a kedvezményezettek javára már megállapított és esedékessé vált kötelezettségek teljesítését. A Kekva tv. ezt csak az alapító okirat módosítása körében írja elő. ${ }^{66} \mathrm{~A}$ fentiekből következően a vagyonkezelői alapítvánnyal szemben a kedvezményezett közvetlenül csak akkor támaszthat igényt, ha a javára teljesített juttatást megállapították, és az már esedékessé vált. ${ }^{67}$

\subsection{A KEDVEZMÉNYEZETT JOGA A VAGYON VISSZAKÖVETELÉSÉRE}

A Ptk. ${ }^{68}$ a bizalmi vagyonkezelés vonatkozásában az angolszász tracing-hez hasonló megoldást tartalmaz. A kedvezményezettet megillető visszakövetelési jog gyakorlásának konjunktív feltételei, hogy a vagyonkezelő szerződéses kötelezettségét szegje meg a vagyontárgy átruházásával, valamint a szerző fél ne legyen jóhiszemü, vagy a szerzés ne legyen visszterhes.

${ }^{60}$ Vatv. 7. $\S(1)$ bekezdés.

${ }^{61}$ Kekva tv. 8. $\S(1)$ bekezdés.

${ }^{62}$ Vatv. 8. $§$ (3) és (4) bekezdés, Kekva tv. 9. $§$ (3) és (4) bekezdés.

${ }^{63}$ Ptk. 6:315. §.

${ }^{64}$ Ptk. 3:387. § A kedvezményezettként megjelölt személy nem támaszthat igényt az alapítvánnyal szemben, kivéve, ha a) az alapító okirat a kedvezményezett személyt, a neki járó szolgáltatást és a teljesítés időpontját a teljesítéshez szükséges módon meghatározza; vagy b) a kuratórium a kedvezményezett részére szóló juttatásról döntött, döntését a kedvezményezettel közölte, és a jogosult a juttatás feltételeit elfogadta.

${ }^{65}$ Vatv. 9. $§(5)$ bekezdés.

${ }^{66}$ Kekva tv. 10. $\$(7)$ bekezdés.

67 Természetesen ez az állítás csak akkor helytálló, ha a kedvezményezett egyben nem alapító is, de ez utóbbi eset is a fenti álítást támasztja alá, hiszen ekkor nem a kedvezményezetti pozíciójából, hanem alapítót megillető jogait érvényesítheti közvetlenül az alapítvánnyal szemben.

${ }^{68}$ Ptk. 6:318. § (2) és (3) bekezdés. 
Fontos hangsúlyozni, hogy az angolszász tracingnek megfelelően a Ptk. a kedvezményezett számára csak a kezelt vagyonba történő visszahelyezésének követelését és nem saját magának történő vindikációs jogot teszi lehetővé. A fentiekből kiindulva a hazai jogban egyértelmủen nem tulajdonjogi, hanem kötelemi jogi igényként értékelhető a kedvezményezett visszakövetelési joga.

A Ptk. ${ }^{69}$ a tracing szabályát rendeli alkalmazni a kezelt vagyontárgy jogosulatlan megterhelésének esetére is. A főszabály a jogosulatlan átruházás esetén a kezelt vagyon számára visszakövetelési jogot biztosít a kedvezményezett és a vagyonrendelő számára. A kezelt vagyon jogosulatlan megterhelése esetében azonban nem a vagyontárgy visszakövetelése, hanem a teher törlése és az eredeti állapot helyreállítása iránt léphet fel a kedvezményezett. Ugyanakkor ez a következtetés csak a jogszabály teleológiai értelmezése alapján vonható le.

Vagyonkezelői alapítvány esetén a hazai szabályozás a kedvezményezett viszszakövetelésének jogát nem rögzíti. Tekintettel arra, hogy a kedvezményezett joga a vagyon kiadására csak abban az esetben nyílik meg, ha azt az alapítvány kezelő szerve részére megítélte és a kiadás esedékessé vált. Ezek hiányában a vagyon felett az alapítvány rendelkezhet, így, ha az alapítvány az alapító okirattal ellentétesen, jogosulatlanul ruház át a kezelt vagyonból a kedvezményezett közvetlenül nem, csak legfeljebb a vagyonellenőr vagy az alapítvány ellenőrző szervei útján léphet fel a kezelt vagyonba történő visszaszerzés érdekében. Ettől a szabálytól mangáncélú vagyonkezelő alapítvány esetén az alapító a létesítő okiratban eltérhet. ${ }^{70}$ Kérdésként merülhet fel, hogy a főszabálytól való eltérés a kedvezményezett jogainak megóvása érdekében mennyire lehet indokolt. Csehi Zoltán a korábbi osztrák és magyar jog vizsgálatát követően arra a konklúzióra jutott, hogy bizonyos alapítói jogok delegálását vagy juttatását a kedvezményezettek részére nem tartja követendőnek. ${ }^{71} \mathrm{~A}$ szerző ezen véleményét egyrészt az osztrák és a magyar jog vizsgálatára, valamint arra alapozza, hogy a kezdeményezettek ingyenes juttatás alanyai, ezért szerepük csakis korlátozott ellenőrzésre jogosíthatja fel őket, nem pedig az alapítvány irányítására. ${ }^{72} \mathrm{~A}$ jogalkotó feltehetően hasonló indokok miatt az eltérést a közcélú vagyonkezelő alapítványok esetén szintén nem tartotta szükségesnek.

\section{ZÁRSZÓ}

Összefoglalva elmondható, hogy a magyar bizalmi vagyonkezelési jogviszony kialakítása a kedvezményezett jogainak érvényesíthetősége vonatkozásában nagymértékben az angolszász szabályozást tükrözi. A magyar jogban is megjelenik az angolszász jogból átvett „tracing” biztosítása, amely alapján a kedvezményezett visszakövetelési jogot kap az olyan harmadik személyekkel szemben, akik a kezelt

${ }^{69}$ Ptk. 6:318. $\S(3)$ bekezdés.

${ }^{70}$ Vatv. 9. $\$(5)$ bekezdés.

71 CseHi Zoltán: A magánjogi alapítvány. Történeti és dogmatikai alapok. (Budapest: Gondolat 2006) 343.

72 CSEHI (57. lj.) 343. 
vagyonból rosszhiszeműen vagy ingyenesen szereznek. A visszakövetelési jog gyakorlásához ugyanakkor a Ptk. a vagyonkezelő szerződéses kötelezettségének megszegését is feltételéül szabja.

A hazai szabályozás a kedvezményezett számára a jogviszonyt létrehozó szerződés szerint vagyonkiadási jogot és ellenőrzési jogot biztosít, amely a magáncélú vagyonkezelő alapítványhoz képest szélesebb jogosultságot jelent, mivel a vagyonkezelői alapítvánnyal szemben a kedvezményezett közvetlenül csak akkor támaszthat igényt, ha a javára teljesített jutatást megállapították, és az már esedékessé vált, ettől csak a magáncélú vagyonkezelő alapítvány esetén van lehetőség eltérni.

A vagyonkezelői alapítvány esetén az alapítványnak számadási kötelezettsége a kedvezményezett iránt nincs. Habár a jogalkotó az ellenőrzés és a törvényes működés garanciája érdekében a vagyonellenőr intézményét a vagyonkezelői alapítvány esetén kötelezően elöírja, ha az alapító az alapítói jogok gyakorlására a kuratóriumot jelölte ki, valamint közfeladatot ellátó közérdekű vagyonkezelő alapítványok esetén, míg a protektor a bizalmi vagyonkezelés esetén csak a diszpozitivitás keretén belül hozható létre. Ugyanakkor az alapítványi vagyonellenőr elsődleges feladata nem a kedvezményezetti jogok biztosítása, hanem a vagyonkezelési tevékenységének jogszerűségének figyelemmel kísérése, így a kedvezményezett a vagyonellenőr tevékenységére nem hathat közvetlenül.

A fentiek alapján megállapítható, hogy a bizalmi vagyonkezelés kedvezményezettje sokkal erősebb pozíciójú, mint a vagyonkezelői alapítvány kedvezményezettje. ${ }^{73}$ A jogalkotó felismerte azt, hogy a magáncélú vagyonkezelői alapítvány funkciója hasonló, így itt lehetőséget biztosított arra, hogy az alapító a létestő okiratban a kedvezményezettek részére akár a bizalmi vagyonkezeléshez hasonló szélesebb igényérvényesítési lehetőségeket biztosíthasson.

A hazai szabályozás kialakulása hasonlóságot mutat a francia fiducie jogintézmény fejlődésének folyamatával. A visszaélések elkerülése érdekében bevezetett engedélyezési követelményeket a francia jogalkotó is fokozatosan enyhítette, és később kiterjesztette a vagyonkezelői kört az ügyvédekre is.

A francia szabályozásban és az uniós szinten is a visszaélések elkerülése érdekében a transzparencia növelését és a jogviszonyban részt vevő tényleges tulajdonosok nyilvántartásba vételét is szorgalmazták. ${ }^{74}$ Azonban, ahogyan a francia Alkotmánytanács is döntésében rámutatott, a tényleges tulajdonosok nyilvántartásában történő betekintési jog csak az alapvető jogok tiszteletben tartása mellett lehetséges. A magyar szabályozás előzetes engedélyezési folyamat előírásával kíván megfelelő garanciát biztosítani a bizalmi vagyonkezelési jogviszony kedvezményezettjeinek.

A kedvezményezett szemszögéből vizsgálva a hazai szabályozást, megállapítható, hogy a kedvezményezett igényérvényesítési lehetősége a bizalmi vagyonkezelővel szemben jobban biztosított, mint egy alapítvánnyal szemben. Tekintettel arra, hogy a kedvezményezett a vagyonkezelői alapítvány által a kezelt vagyon jogelle-

73 B. Szabó-Menyhei-SÁndor (25. lj.) 277.

${ }^{74}$ Ld. az Irányelv alapján előírt nyilvántartás bevezetését. 
nes elidegenítésekor legfeljebb csak a vagyonellenőrön vagy az ellenőrző szerveken keresztül próbálhat meg fellépni, valamint a kiadás iránti jogait is csak a juttatás megítélése és a kiadás esedékessége esetén gyakorolhatja. ${ }^{75} \mathrm{~A}$ bizalmi vagyonkezelő esetén azonban a jogellenes elidegenítés esetén történő kedvezményezett igényérvényesítését a Ptk. lehetővé teszi. Továbbá bizalmi vagyonkezelési szerződés alapján járó kiadás esetén már a szerződés alapján, külön juttatás megállapítása nélkül is megnyílik az igénye a kezelt vagyonra nézve.

Különbségei ellenére ugyanakkor fontos kiemelni, hogy a hazai jogban megjelenő vagyonkezelői alapítvány és a bizalmi vagyonkezelés intézménye elsősorban nem egymás alternatíváiként szolgálnak, hanem a vagyonkezelési tevékenység jogi eszköztárát bővítik. Ezt példázza, hogy a vagyonkezelői alapítványnak ${ }^{76}$ és a közfeladatot ellátó közérdekű vagyonkezelő alapítványnak ${ }^{77}$ is lehetősége van bizalmi vagyonkezelésbe venni vagyontárgyakat.

A vagyonkezelő alapítvány szabályozásának bizalmi vagyonkezeléshez való közelítése, valamint a hatályos szabályozás további kiegészítése várhatóan a kedvezményezetti jogok további biztosításának érdekében valósul majd meg. Ez a folyamat pedig megfelelően illeszkedik a trust-konstrukciók kialakításának nemzetközi tendenciájába, így a kívánatos vagyonkezelési modell megtalálása további kihívások elé állítja majd a jogalkalmazókat és a jogalkotót egyaránt.

75 Magáncélú vagyonkezelő alapítvány esetén ettől való eltérésre lehetőség van.

76 Vatv. 2. $\S(2)$ bekezdése.

77 Kekva tv. 3. § (6) és (7) bekezdései. 